\title{
Omacetaxine Mepesuccinate
}

National Cancer Institute

\section{Source}

National Cancer Institute. Omacetaxine Mepesuccinate. NCI Thesaurus. Code C1127.

A semisynthetic formulation of the cytotoxic plant alkaloid homoharringtonine isolated from the evergreen tree Cephalotaxus with potential antineoplastic activity. Omacetaxine mepesuccinate binds to the $80 \mathrm{~S}$ ribosome in eukaryotic cells and inhibits protein synthesis by interfering with chain elong ation. This agent also induces differentiation and apoptosis in some cancer cell types. 